\title{
Ketotic hypoglycaemia of childhood
}

\author{
A. M. PIERIDES* \\ M.B., M.R.C.P. \\ J. ANDERSON* \\ M.B., B.S., F.R.C.P. \\ J. M. StANSFELD $\dagger$ \\ M.D., F.R.C.P.

\begin{abstract}
*University Department of Medicine, Royal Victoria Infirmary, Newcastle upon Tyne, and $\dagger$ The Durham Hospitals
\end{abstract}

\begin{abstract}
Summary
A patient with recurrent convulsions in childhood and associated ketotic hypoglycaemia is described. Hypoglycaemic attacks started at the age of 3 years and 4 months and continued until 9. At present (aged 15) the patient is mentally retarded, has epilepsy, high tone deafness and a major behaviour disturbance. Prednisone therapy failed to prevent hypoglycaemic convulsions and eventually irreversible brain damage. Intramuscular glucagon and adrenaline were ineffective in raising the blood glucose during acute hypoglycaemic attacks.
\end{abstract}

Investigations at 3 years and 7 months and at 14 years showed a persistent and markedly abnormal sensitivity to a small dose of exogenous insulin with severe hypoglycaemia with convulsions, absence of clinical hyperadrenalism during hypoglycaemia, and a metabolic block in gluconeogenesis. The demonstration of a persistent biochemical abnormality of glucose metabolism at the age of 14 strongly suggests that ketotic hypoglycaemia of childhood is not another aspect of nutritional deprivation, as recently suggested (Buist, 1974), but the result of a defect in glucose homeostasis.

\section{Introduction}

Ketotic hypoglycaemia associated with convulsions was first described by Ross and Josephs in 1924. In their classical paper they described such a patient, established the relationship of ketotic hypoglycaemia to withdrawal of dietary carbohydrate and described the inability of adrenaline to raise the blood glucose during a hypoglycaemic episode. Over the ensuing years independent workers (mainly in the U.S.A.) confirmed the existence of this syndrome (Griffith, 1929; Rector and Jennings, 1937; Colle and Ulstrom, 1964; Habbick, McNeish and Stephenson, 1971; Chaussain, 1973), and the natural history has been accurately described.

Correspondence: Dr A. M. Pierides, Department of Medicine, Royal Victoria Infirmary, Newcastle upon Tyne NE1 4LP.
Following the description of the clinical syndrome and the realization that susceptible children were unable to maintain normal blood glucose levels under provocation with a ketogenic diet or with starvation, a defect in gluconeogenetic pathways or a deficit in the glucose precursor pool were suspected. Senior and Loridan (1969) found no abnormality in the pathways converting glycerol to glucose but Pagliara et al. (1972) demonstrated a block in the glucose-alanine cycle important in gluconeogenesis; low L-alanine levels were found in these patients and they fell even further after starvation or provocation with ketogenic diet. Intravenous L-alanine corrected both the hypoglycaemia and ketosis of an acute hypoglycaemic episode.

Recently there has been doubt whether this condition is a disease entity or one end of the normal spectrum (Buist, 1974). The patient described here demonstrates the persistence of a gluconeogenetic block from the age of $3 \frac{1}{2}$ to 14 years and lends support to the concept that ketotic hypoglycaemia of childhood may be an entity of its own.

\section{Case history and results}

A 15-year-old child was referred to the Medical Unit at the Royal Victoria Infirmary, Newcastle upon Tyne, for investigation of epilepsy and reassessment of his endocrine status and carbohydrate metabolism in view of the prolonged and well documented attacks of hypoglycaemia in childhood. He was born in 1959 at 35 weeks' gestation with a birthweight of $5 \mathrm{lb}$. The mother had pre-eclampsia. All went well until the age of 3 years and 4 months when one morning at 06.45 hours the child was found convulsing. After an emergency hospital admission a lumbar puncture revealed a normal protein level and cell count. Unfortunately no glucose estimations were carried out. The child improved and the convulsion was attributed to a septic finger the child had for a week before admission. Four months later the child was admitted once more in status epilepticus having been found at 
TABLE 1. Details of hospital admissions. Evidence for the syndrome of ketotic hypoglycaemia of childhood

\begin{tabular}{|c|c|c|c|c|c|}
\hline \multirow[b]{2}{*}{ Date } & \multirow{2}{*}{$\begin{array}{l}\text { Age } \\
\text { in } \\
\text { years }\end{array}$} & \multirow[b]{2}{*}{$\begin{array}{c}\text { Circumstances precipitating } \\
\text { admission }\end{array}$} & \multirow[b]{2}{*}{$\begin{array}{l}\text { Treatment before } \\
\text { admission }\end{array}$} & \multicolumn{2}{|c|}{ On admission } \\
\hline & & & & $\begin{array}{l}\text { Urine } \\
\text { acetone }\end{array}$ & $\begin{array}{l}\text { Blood } \\
\text { glucose }\end{array}$ \\
\hline 24.6 .62 & $3^{4} / 12$ & $\begin{array}{l}6.45 \text { a.m. found unconcious } \\
\text { and convulsing. Two more } \\
\text { fits in hospital the following } \\
\text { morning }\end{array}$ & Immediate therapy-none & Not known & Not teste \\
\hline 18.10 .62 & $37 / 12$ & $\begin{array}{l}9 \text { a.m. convulsions following } \\
\text { large vomit. Convulsions } \\
\text { intermittently until } 5 \text { p.m. }\end{array}$ & Immediate therapy-none & Not known & $\begin{array}{l}4.30 \text { p.m. } \\
24 \mathrm{mg}^{\circ}\end{array}$ \\
\hline
\end{tabular}
intermittently until 5 p.m.

$24 \mathrm{mg} \%$

4.7 .63

$4 \frac{4}{12} \quad 5$ a.m. staring of the eyes with Immediate therapy-none generalised convulsions. Repeated vomiting for $18 \mathrm{hr}$ before admission

28.8.63 $4 \frac{5}{12}$ Onset of drowsiness while playing. No convulsions

Glucose at home

Not known $100 \mathrm{mg}$

25.10.63 $4 \frac{7}{12}$ Onset of drowsiness and unresponsiveness

17.12.63 $4 \% / 12 \quad$ Hypoglycaemic attack with drowsiness, slurred speech and convulsions 5 p.m.

1.1.64 $4 \frac{10}{12} \quad 5.45$ p.m. unresponsiveness and twitching

12.2.64 $411 / 12 \quad 10$ a.m. drowsiness with unresponsiveness

27.6.64 $53 / 12 \quad$ Unconsciousness with unresponsiveness for $24 \mathrm{hr}$. Vomiting profusely for $12 \mathrm{hr}$ before admission

15.9.64 $56 / 12 \quad 5.30$ a.m. convulsions with drowsiness and vomiting $\begin{array}{lll}27.10 .64 & 57 / 12 & \begin{array}{c}\text { Unresponsiveness with } \\ \text { drowsiness following }\end{array}\end{array}$ vomiting for $12 \mathrm{hr}$

$30.11 .64 \quad 58 / 12 \quad 10$ a.m. staring gaze with convulsions and ensuing drowsiness

1.1.65 $510 / 12$ Attack of measles

9.4.65 $61 / 12$ Waiting list admission for repair of left inguinal hernia
Glucose drink by mother. Not known $225 \mathrm{mg} \%$ Sub-cutaneous adrenaline by G.P.

Glucose drink at home Not known -

Glucose drink. Glucagon Not known intramuscularly by G.P.

9.10 p.m. $85 \mathrm{mg} \%$

Intramuscular glucagon $\times 3$ with no improvement

Glucose drinks. Glucagon Acetone $++142 \mathrm{mg} \%$ i.m. $\times 2$. No effect

Oral glucose. i.v. dextrose Acetone by G.P. $++$

\section{i.v. dextrose}

Oral and i.v. glucose

$\begin{gathered}\text { Acetone } \\ +++\end{gathered}$
Not tested
$\begin{gathered}\text { No acetone } \\ \text { present }\end{gathered}$

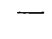

$-$
.30 a.m. $28 \mathrm{mg} /$

or

Pred

CSF glucose $=19 \quad \vec{\circ}$ $\mathrm{mg} \%$ GTT flat. Noevidence of leucine $\vec{\omega}$ sensitivity. Extreme $\sigma$ sensitivity to insulin tolerance curve. Started on prednisone $5 \mathrm{mg}$ daily

i.v. glucose given in hospital with good effect. Discharged on prednisone $7 \cdot 5 \mathrm{mg}$ daily

Prednisone increased to $5 \mathrm{mg}$ b.d. 29.8 .63 Fasting glucose $35 \mathrm{mg} \%$

Prednisone increased to $5 \mathrm{mg}$ t.d.s. Repeat GTT flat $\bigcirc \overrightarrow{0}$

Fasting urine speci ㅏ men 19.12.63 showed acetone $+?$ Fasting blood glucose $18.12 .6358 \mathrm{mg} \%$

urine specimen over $\mathbb{Q}$ the next three days

Acetonuria the following day

Plasma bicarbonate $15.9 \mathrm{mEq} / \mathrm{l}$. Marked acetone in breath. 28.6.64 marked acetonuria

Fasting acetonuria over the following days. Treatment with prednisone $5 \mathrm{mg}$ b.d. continued

Definite evidence of mental backwardness

W

v

인

Prolonged convulsions in hospital. Post op. (11.4.65) i.m. glucagonNo response. Marked acetonuria 


\begin{tabular}{|c|c|c|c|c|c|c|}
\hline \multirow[b]{2}{*}{ Date } & \multirow{2}{*}{$\begin{array}{c}\text { Age } \\
\text { in } \\
\text { years }\end{array}$} & \multirow[b]{2}{*}{$\begin{array}{c}\text { Circumstances precipitating } \\
\text { admission }\end{array}$} & \multirow[b]{2}{*}{$\begin{array}{l}\text { Treatment before } \\
\text { admission }\end{array}$} & \multicolumn{2}{|c|}{ On admission } & \multirow[b]{2}{*}{$\begin{array}{l}\text { Comments and } \\
\text { investigations }\end{array}$} \\
\hline & & & & $\begin{array}{l}\text { Urine } \\
\text { acetone }\end{array}$ & $\begin{array}{l}\text { Blood } \\
\text { glucose }\end{array}$ & \\
\hline 11.8 .65 & $6^{5} / 12$ & 6.30 a.m. convulsions & Glucose & $\begin{array}{l}\text { Trace of } \\
\text { acetone }\end{array}$ & $109 \mathrm{mg} /$ & - \\
\hline 9.11 .65 & $6^{8} / 12$ & $\begin{array}{l}7.30 \text { a.m. convulsions with } \\
\text { coma }\end{array}$ & Oral glucose & $\begin{array}{l}\text { Acetone } \\
+++\end{array}$ & $30 \mathrm{mg} \%$ & - \\
\hline 13.10 .66 & $77 / 12$ & $\begin{array}{l}7.45 \text { a.m. convulsions with } \\
\text { drowsiness }\end{array}$ & Oral glucose & Not known & $199 \mathrm{mg} \%$ & 一 \\
\hline 28.11 .66 & $7^{8} / 12$ & 6.45 a.m. convulsions & Oral glucose & Not known & - & - \\
\hline 8.9.67 & $86 / 12$ & $\begin{array}{l}6.45 \text { a.m. convulsions with } \\
\text { intermittent drowsiness }\end{array}$ & Oral glucose & Not known & $\begin{array}{l}9.30 \text { a.m. } \\
30 \mathrm{mg} / \mathrm{O}\end{array}$ & $\begin{array}{l}50 \mathrm{ml} 50 \% \text { i.v. dex- } \\
\text { trose. Confused for } \\
\text { several hours. } \\
\text { Completely well the } \\
\text { following day. } \\
\text { Treatment with } \\
\text { prednisone } 2 \cdot 5 \mathrm{mg} \\
\text { daily continued and } \\
\text { stopped in April } \\
1968 \text {. Started on } \\
\text { phenobarbitone } \\
30 \mathrm{mg} \text { b.d. }\end{array}$ \\
\hline 20.10 .68 & $97 / 12$ & $\begin{array}{l}\text { Rolling of eyes with } \\
\text { drowsiness }\end{array}$ & Oral glucose & Not known & $\begin{array}{l}9.15 \\
100 \mathrm{mg} \%\end{array}$ & $\begin{array}{l}\text { Phenobarbitone } \\
\text { treatment stopped } \\
\text { five days before } \\
\text { admission. Attack } \\
\text { most likely epileptic } \\
\text { in nature }\end{array}$ \\
\hline
\end{tabular}

08.30 hours convulsing and vomiting. Blood glucose was $24 \mathrm{mg} \%$ and CSF glucose was $19 \mathrm{mg} \%$. Intravenous glucose was given with effect. Over the next 6 years the child had a series of hospital admissions with episodes of hypoglycaemia (Table 1). During the first few admissions urine was not routinely tested, but later on acetonuria was found whenever the child was admitted hypoglycaemic. During these admissions, extensive endocrine investigations were carried out. The child was shown to be extremely sensitive to a small amount of exogenous insulin and during hypoglycaemia adrenaline was ineffective in raising blood glucose. By the age of 9 the hypoglycaemic attacks ceased, but attacks of minor epilepsy, characterized by rolling of the eyes, difficulty with focusing and transient loss of concentration, occurred at intervals. Less infrequently, he had grand mal attacks usually at night, with loss of consciousness and generalized convulsions. The child developed a behaviour disturbance with aggressive characteristics particularly evident at school.

On admission to the Medical Unit in September 1973 examination revealed a simple, retarded child. He had a mild stammer and the estimated developmental score was 6.5 years. His arm span was $158 \mathrm{~cm}$, height $163 \mathrm{~cm}$ and pubis-to-ground length $80 \mathrm{~cm}$. His secondary sex characteristics were well developed. Blood pressure was $115 / 75 \mathrm{mmHg}$, pulse 72 beats/
TABle 2. Prolonged oral glucose tolerance test $(50 \mathrm{~g})$.

\begin{tabular}{lllllllllll}
\hline Time (hr) & 0 & $\frac{1}{2}$ & 1 & $1 \frac{1}{2}$ & 2 & $2 \frac{1}{2}$ & 3 & 4 & 5 & 6
\end{tabular}
$\begin{array}{lllllllllll}\text { Glucose }(\mathrm{mg} \%) & 84 & 86 & 94 & 82 & 80 & 78 & 74 & 70 & 70 & 68\end{array}$ $\begin{array}{llllllllllll}\text { Insulin }(\mu \mathrm{u} / \mathrm{ml}) & 6 & 10 & 10 & 13 & 9 & 3 & 3 & 3 & 6 & 3\end{array}$

min and cardiovascular and respiratory systems were normal. Neurological examination revealed no abnormality. The haemoglobin was $13.7 \mathrm{~g} \%$, ESR $2 \mathrm{~mm}$, serum iron $75 \mu \mathrm{g} \%$, iron binding capacity $315 \mu \mathrm{g} \%, \mathrm{~B}_{12}$ level $380 \mathrm{pg} / \mathrm{ml}$, folic acid $7 \cdot 1 \mathrm{ng} / \mathrm{ml}$, urea $28 \mathrm{mg} \%$, serum creatinine $0.7 \mathrm{mg} \%$, serum calcium $9.7 \mathrm{mg} \%$, phosphate $4.7 \mathrm{mg} \%$, alkaline phosphatase $230 \mathrm{u} / 1 \mathrm{WR}$ and VDRL negative. Chest skull X-rays were normal. Urinary amino-acid paper chromatography showed a mild, non-specific aminoaciduria. Two estimations of 24-hr urinary 17hydroxy and oxosteroid excretion were normal (12.3, $10.8 \mathrm{mg}$, and $6.7,5.4 \mathrm{mg}$ respectively); 09.00 hours plasma cortisol $8.3 \mu \mathrm{g} \% ; 09.00$ hours plasma ACTH $25 \mathrm{pg} / \mathrm{ml}$; midnight plasma cortisol $3.3 \mu \mathrm{g} \%$; midnight plasma ACTH less than $15 \mathrm{pg} / \mathrm{ml}$. Synacthen test was normal. Five day faecal fat was $4.5 \mathrm{~g} /$ day. A jejunal biopsy was normal. Electroencephalography showed an irregular and abnormal record compatible with diffuse cerebral damage, more marked on the right.

A prolonged oral glucose tolerance test (Table 2) showed a flat curve (in keeping with previous 
TABLE 3. Intravenous glucose tolerance test (35 g).

\begin{tabular}{lrrrrrrr}
\hline Time $(\mathrm{min})$ & 0 & 10 & 20 & 30 & 40 & 50 & 60 \\
Glucose $(\mathrm{mg} / \mathrm{o})$ & 68 & 158 & 114 & 90 & 80 & 78 & 74 \\
Insulin $(\mu \mathrm{u} / \mathrm{ml})$ & 2 & 25 & 8 & 5 & 5 & 0 & 0 \\
\hline
\end{tabular}

' $\mathrm{k}$ ' value $=4 \cdot 6 \% / \mathrm{min}$.

TABLE 4. Insulin sensitivity test $(0 \cdot 1 \mathrm{u} / \mathrm{kg}=4$ units $)$, carried out at the age of 14 years.

\begin{tabular}{lcccccc}
\hline Time $(\mathrm{min})$ & 0 & 30 & 45 & 60 & 90 & 120 \\
Glucose $(\mathrm{mg} \%)$ & 84 & $<0$ & $<20$ & $<20$ & 20 & $<20$ \\
Cortisol $(\mu \mathrm{g} \%)$ & 8.9 & 10 & $16 \cdot 2$ & $18 \cdot 2$ & $19 \cdot 8$ & $2 \cdot 30$ \\
A.C.T.H. $(\mathrm{pg} / \mathrm{ml})$ & 66 & 65 & 130 & 110 & 105 & 178 \\
$\begin{array}{l}\text { Growth hormone } \\
(\mu \mathrm{g} / \mathrm{ml})\end{array}$ & 13 & 6.6 & 105 & 260 & 230 & 240 \\
\hline
\end{tabular}

measurements). There was no reactive hypoglycaemia and only minimal secretion of insulin. Intravenous glucose tolerance test (Table 3 ) showed an early rise in glucose and insulin levels but they were at the lower limit of normal. The calculated ' $k$ ' value was $4.6 \% / \mathrm{min}$ (Amatuzio, 1964). Normal range: $3 \cdot 01-4.85 \% / \mathrm{min}$ ). An insulin tolerance test (Table 4) showed marked sensitivity to a small dose $(0 \cdot 1 \mathrm{u} / \mathrm{kg})$ with prolonged hypoglycaemia. Clinically there was no evidence of hyperadrenalinism or hypoglycaemia until on completing the test the patient had a generalized convulsion quickly controlled with intravenous glucose and hydrocortisone. A glucagon test after a 12-hr fast did not produce any significant rise in glucose, or insulin release. A limited 26-hr provocation test with a ketogenic diet designed to provide $1200 \mathrm{cal} / 1.73 \mathrm{~m}^{2}$ of body surface was carried out. There was no hypoglycaemia during the study but at $12 \mathrm{hr}$ mild acetonuria appeared, increasing considerably at $24 \mathrm{hr}$. Intravenous L-alanine prepared, as described by Pagliara et al. (1972), was given over $15 \mathrm{~min}$ at $25.5 \mathrm{hr}$, and within $2 \mathrm{hr}$ all acetonuria cleared.

Since the age of 9 , no attack of hypoglycaemia has occurred and epilepsy is controlled with appropriate anticonvulsant therapy.

\section{Discussion}

The syndrome of ketotic hypoglycaemia appears to be the commonest cause of recurrent hypoglycaemic convulsions in children (Kogut, Blaskovics and Donnell, 1969; Chaussain, 1973; Christensen, 1974). The frequency of mental retardation, epilepsy, and brain damage with all the physical and social sequelae has been reported as over $30 \%$ (Kogut et al., 1969). This emphasizes the importance of early diagnosis and management for it seems that this is a treatable condition. Low birthweight children are preferentially affected, onset is usually between the ages of 2 and 5 years and spontaneous improvement occurs by the age of 8-9 years (Habbick et al., 1971; Pagliara et al.. 1973). The reason why the syndrome becomes clinically evident between $\stackrel{\mathbb{1}}{\varrho}$ the ages of 2 and 5 and gradually settles by the age of $c$. 9 is still not well understood. Senior and Loridan $\vec{F}$ (1969) thought that the amelioration with growth $\stackrel{\text { ? }}{+}$ could reflect an increase in size of the pool of glucose precurosrs and noted that a similar amelioration with $\frac{\overline{\bar{c}}}{\bar{\rho}}$ age occurs in type III glycogenosis despite the $\frac{\bar{\Phi}}{\widehat{D}}$ persistence of the enzymatic disorder.

The glucose-alanine cycle is an important mechanism for gluconeogenesis and may act as an end- $\overrightarrow{0}$ pathway through which many other factors operate ${ }_{-}^{\circ}$ to contribute to gluconeogenesis (Felig, 1973). The $\vec{\omega}$ demonstration of an abnormality in the glucose- $\rightarrow$ alanine cycle with low, depleted, basal L-alanineo levels and rapid reduction during provocation with a ketogenic diet and insulin is important in explain- -9 ing the undue sensitivity exhibited by such patientso to small doses of exogenous insulin. As early as 1937, Hartmann, Jaudon and Morton commented on $\omega$ the striking intolerance to insulin of this group of $N$ patients and reported that in two of their patients? hypersensitivity to insulin persisted for 3 years after $\overrightarrow{ }$ the first examination. In our patient this abnormalityo persisted to the age of 14 and injection of a small dose of insulin $(0 \cdot 1 \mathrm{u} / \mathrm{kg})$ resulted in a convulsion. Similar findings, also with generalized convulsions, $\vec{c}$ were found by Broberger, Jungmer and Zetterstron w (1959) in three children. In our patient, all other hormonal reactions, including ACTH release, corti-O sol and growth hormone responses, appeared normal (Table 4). Broberger et al. (1959), Köffler, Schubert and Hug (1971) and Christensen (1974) alsoo demonstrated failure of adrenaline secretion during an insulin provocation test, and this observation $\overrightarrow{\hat{O}}$ could explain the clinical observation of lack of any 3 clinical signs before the onset of convulsions during such a test, in the presence of severe hypoglycaemia. This observation is of great importance, for know=o ledge of this discrepancy between the presence of $\mathrm{P}$. hypoglycaemia and the absence of clinical symptoms should ensure that such children are not left in. prolonged hypoglycaemia often with detrimentalo results. If ketotic hypoglycaemia is suspected and an insulin sensitivity test is thought to be necessary, a음 smaller dose of insulin-such as $0.05 \mathrm{u} / \mathrm{kg}$-should be used to minimize the dangers of excessive hypo-․ㅡ. glycaemia. The explanation of the failure of adrena-n line response has until recently remained a puzzle: Goodall, Cragan and Sidbury (1972) thought thato delayed maturation of the adrenal medulla was aw likely explanation but clearly this is now unaccept able since the abnormality persists until after pubertyo Tietze et al. (1972) favoured a central neurologica hypothalamic explanation but again no convincing? evidence of such an abnormality is available. Flatto et al. (1974) have recently shown that in the presence of ketosis adrenaline secretion is impaired. These? 
workers were able to show that in anaesthetized dogs adrenaline secretion after insulin stimulation could be prevented by infusion of ketone bodies to sustain a blood ketone concentration of 1-2 mmol/1. Earlier Drennick, Alvarez and Tamasi (1972) in a study involving insulin sensitivity tests in obese patients before and after starvation noted a marked failure of adrenaline secretion during the repeat insulin sensitivity test. The mean $\beta-\mathrm{OH}$ butyrate plasma concentration was $8.02 \mathrm{mmol} / \mathrm{l}$. During the second insulin sensitivity test, hypoglycaemia was more severe but clinically silent. These experimental findings reproduce some of the findings in patients with ketotic hypoglycaemia of childhood and add weight to the possibility that the presence of ketosis may be responsible for the failure of adrenaline secretion and clinically silent hypoglycaemia, There is, therefore, evidence that ketotic hypoglycaemia of childhood is the result of an abnormality of glucose homeostasis, mainly involving the rate of production of L-alanine in the peripheral muscle and thus interfering with gluconeogenesis and the ability to maintain adequate blood glucose levels.

Reports during the last 50 years, mainly restricted to the U.S.A. and Europe, of children from different family backgrounds and nutritional status, make it unlikely that this syndrome is the result of nutritional deprivation. The episodes of hypoglycaemia appear to be the result of a basic defect in gluconeogenesis in the presence of an otherwise normal endocrine system and the associated ketosis, a useful clinical marker, may be responsible for the failure of adrenaline secretion and clinically silent hypoglycaemia.

\section{Conclusion}

A patient with ketotic hypoglycaemia of childhood and mental retardation due to uncontrollable episodes of hypoglycaemia is described. For the first time, a basic abnormality of glucose homeostasis has been demonstrated persisting from the age of 3 years and 7 months to the age of 14,5 years after spontaneous episodes of hypoglycaemia ceased. This finding suggests that nutritional deprivation is a very unlikely cause of this syndrome, although it could on occasions be responsible for aggravating the tendency to hypoglycaemia and thus precipitate attacks of hypoglycaemia.

\section{References}

Amatuzio, D.S. (1964). In: Diabetes Mellitus, Diagnosis and Treatment. American Diabetes Association Inc., New York, N.Y. 10017.
Broberger, O., Jungmer, I. \& Zetterström, R. (1959) Studies in spontaneous hypoglycemia in childhood. Failure to increase the epinephrine secretion in insulin-induced hypoglycemia. Journal of Pediatrics, 55, 713.

Buisr, N.R.M. (1974) Ketotic hypoglycaemia. British Medical Journal, 2, 730.

Chaussain, J.L. (1973) Glycemic response to 24-hour fast in normal children and children with ketotic hypoglycemia. Journal of Pediatrics, 82, 438.

Christensen, N.J. (1974) Hypoadrenalinemia during insulin hypoglycemia in children with ketotic hypoglycemia. Journal of Clinical Endocrinology and Metabolism, 38, 107.

Colle, E. \& Ulstrom, R.A. (1964). Ketotic hypoglycemia. Journal of Pediatrics, 64, 632.

Drennick, E.J., Alvarez, L.C. \& Tamasi, G.C. (1972) Resistance to symptomatic insulin reactions after fasting. Journal of Clinical Investigation, 51, 2757.

Felig, P. (1973). The glucose-alanine cycle. Metabolism, 22, 179.

Flatt, J.P., Blackburn, G.L., Randers, G. \& Stanbury, J.B. (1974) Effects of ketone body infusion on hypoglycemic reaction in postabortive dogs. Metabolism, 23, 151.

Goodall, M., Cragan, M. \& Sidbury, J. (1972) Decreased epinephrine excretion in idiopathic hypoglycemia. American Journal of Diseases of Children, 123, 569.

GRIFFITH, J.P.C. (1929) Hypoglycemia and the convulsions of early life. Journal of the American Medical Association, 93, 1526.

Habbick, B.F., McNeish, A.S. \& Stephenson, J.B.P. (1971 Diagnosis of ketotic hypoglycaemia of childhood. Archive(t) of Disease in Childhood, 46, 295.

Hartmann, A.F., Jaudon, J.C. \& Morton, M. (193 Hypoglycemia. Journal of Pediatrics, 11, 1.

KöfFler, H., Schubert, W.K. \& Hug, G. (1971) Sporadic hypoglycemia: Abnormal epinephrine response to the ketogenic diet or to insulin. Journal of Pediatrics, 78, 448.

Kogut, M.D., Blaskovics, M. \& Donnell, G.N. (1969) Idiopathic hypoglycemia. A study of twenty-six children. Journal of Pediatrics, 74, 853.

Pagliara, A.S., Karl, I.E., De Vivo, D.C., Feigin, R.D. \& KIPRIS, D.M. (1972) Hypoalaninemia: A concomitant of ketotic hypoglycemia. Journal of Clinical Investigation, 51, 1440.

Pagliara, A.S., Karl, I.E., Haymond, M. \& KiPnis, D.M. (1973) Hypoglycemia in infancy and childhood. Journal of Pediatrics, 82, Part I, 365 and Part II, 558.

ReCtor, J.M. \& Jennings, R.E. (1937) Functional hypoglycemia of childhood. American Journal of Diseases of Children, 53, 1012.

Ross, S.G. \& Josephs, H.W. (1924) Observations of the 윽 metabolism of recurrent vomiting. American Journal of $D$ Diseases of Children, 28, 447.

SENIOR, B. \& LORIDAN, L. (1969) Gluconeogenesis and insulin in the ketotic variety of childhood hypoglycemia $\Omega$ and in control children. Journal of Pediatrics, 74, 529.

TIETZE, H.U., ZuRbrügG, R.P., ZuPPINGER, K.A., Joss, E.E. స్ \& KASER, H. (1972) Occurrence of impaired cortisol $\omega$ regulation in children with hypoglycemia associated with adrenal medullary hyporesponsiveness. Journal of Clinical Endocrinology and Metabolism, 34, 948. 